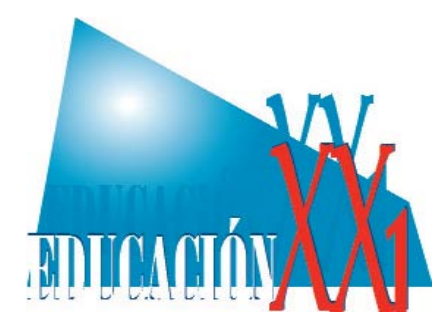

ISSN (VERSIÓN ELECTRÓNICA): 2174-5374

\title{
META-ANALYSIS OF THE RESEARCH ABOUT MOOC DURING 2013-2014
}

\author{
Albert Sangrà \\ Universitat Oberta de Catalunya \\ Mercedes González-Sanmamed \\ Universidad de A Coruña \\ Terry Anderson \\ Athabasca University
}

Cómo referenciar este artículo/How to reference this article:

Sangrà, A.; González-Sanmamed, M. y Anderson, T. (en prensa). Meta-analysis of the research about mooc during 2013-2014. Educación XX1

Sangrà, A.; González-Sanmamed, M. \& Anderson, T. (in press). Meta-analysis of the research about mooc during 2013-2014. Educación XX1

\section{ABSTRACT}

The first MOOC (Massive Open Online Course) was launched in 2008 in Canada. Since then these new model of online education has proliferated around the world and sparked many interesting and often heated discussions regarding their benefits and implications in the field of education. In order to understand and contribute to the debate surrounding MOOCs and their educational possibilities it is necessary to go beyond opinion, intuition or isolated experiences. It is necessary to have evidence that allows for systematic, detailed and contrastive evaluation.

Following the methodology used in an earlier investigation that analyzed publications from the first five years of MOOC delivery, this article looks at studies that focus on MOOCs between 2013-2014. Through a systematic search of the available literature, we found 228 investigative works, published in peer reviewed journals. A quantitative and qualitative analysis of these publications is presented. Classification was based on the year of publication, the type of publication and eleven distinct categories we found of interest. 
We found that increases in the number of publications and, to a lesser extent, presentations at conferences. Pedagogical strategies are the most common focus as well as learner motivation, presentence and implications for higher education systems.

The reach/scope of the MOOC phenomenon for online teaching has sparked and challenged both institutions (their structure, pedagogical model, management and business) as well as instructors (their roles and competencies). In order for answers to be able to settle in what the evidence in the investigation has been building, it is necessary to agree on a common set of topics and research methodologies.

\section{KEYWORDS}

MOOC; virtual education; higher education; online courses; open education; learning environments

\section{INTRODUCTION}

MOOC is an acronym for massive open online course. Massive because its aim is to scalable to as large number of learners as possible - potentially to hundreds of thousands- as opposed to courses aimed at a limited number of participants. Open because the course lacks any restrictions and requirements to gain access - it uses resources that are not proprietary and are open to the community without having to pay any authorship fees in order to use them -although this doesn't match with some of them: i.e. Coursera-, and because it is free. Finally, online because it is conducted online in a virtual context accessible any time and any place.

The first course to be given the name MOOC was run in Canada in 2008. It was called CCK08: Connectivism and Connective Knowledge and its authors were George Siemens and Stephen Downes. The course was offered to students who were registered at the University of Manitoba, but the novelty was that it was open to any who wanted to participate, with the aim of demonstrating the power of connections between and networks among people over the internet for learning and training. The only condition was that the teachers would only assess those students registered at the university. The rest would be participating in self-evaluation activities and peer evaluations in order to determine their progress and their grasp of the subject matter. It surpassed all expectations: more than 2,200 participants enrolled.

In 2009, Sebastian Thrun and Peter Norvig of Stanford University developed the MOOC Introduction to Artificial Intelligence, which convened, according to the university's own sources, more than 120,000 participants from around the world. This MOOC, however, did not have the same objective as that developed by Siemens and Downes. In this case the collaborative and connectivist components morphed into a transmissive approach, which highlighted information from the two Stanford professors.

Later in 2012 the MOOC phenomenon became a widely discussed and debated. Pappano (2012) echoed this in an interview in the New York Times dubbing 2012 as The 
Year of the MOOC. This newspaper synthesized movements that had occurred in the North American educational market that year. The article focussed on three business initiatives created to commercially develop and exploit the MOOC model: Coursera, edX, and Udacity. Coursera is a joint venture between venture capitalists and an eminently commercial and considerably aggressive strategy was decided upon. EdX revolved from an agreement between the Massachusetts Institute of Technology (MIT) and Harvard University and was structured as a non-profit company whose goal was to research and improve online learning. The third, Udacity, was created by Sebastian Thrun, mentioned earlier, as a spin off from Stanford University with a view to a commercial end as well. In Spain, driven by Telefónica, Banco Santander, and Universia, MiríadaX was introduced with the objective of becoming the Spanish language MOOC platform.

The rise of online education, however, is not isolated nor has it descended from the creation of some of these early MOOCs. Babson College's annual reports (and previously those of the Sloan Foundation) demonstrate that online learning has increased in the United States by between 12 and 20\% in the last seven or eight years (Allen and Seaman, 2013). Virtually all North American college students have taken at least one online course during their university career, and the expectation is that this figure will increase. However, a fundamental aspect of this recent explosion can be observed in the behaviour of the so-called top tier universities. These universities have generally ignored the existence of online education for the last fifteen years but now consider it (often using a MOOC strategy) as a strategic element of their future development. The increase in the cost of higher education in the United States has contributed to these universities' shift in thinking that online education could now be the solution to reducing costs, even though that approach has always generated serious doubts, as shown in many studies (Rumble, 2004; Daniel, Kanwar and Uvalic-Trumbic, 2009; Bates and Sangrá, 2011; Contact North, 2014).

The year of the MOOC generated a considerable amount of literature, especially in journals and newspapers. These articles were generally positioned for or against MOOCs based on the insights and opinions of experts, or presentations of research that had been conducted with greater or lesser success, but with little or no systematic evaluation. This, nevertheless, generated interesting discussions providing, more considerably more questions than answers, many of which begged of empirical research to resolve. What follows is a brief summary of the topics that deserved -and in some cases, still deserve- researchers, administrators, politicians and the general public.

Undoubtedly the MOOC phenomenon has put online education in the media and public spotlight. While many open, public and private institutions have been offering not only online courses, but also completely accredited online programs for twenty years, many others have discovered the potential (and challenges) of online education only very recently.

The philosophy of openness and the absence of access restrictions to these courses, beyond the obvious need to have available the communication and the 
necessary devices, could help to democratize access to certain knowledge and help it reach those places where education provision fails to meet demand (Rizvi, Donnelly and Barber, 2013). However, others argue that this so-called democratization is in reality non-existent, since those who are studying MOOCs are, overwhelmingly, people with a university education and from developed countries (O'Shea et al., 2013).

Another consideration is the role that these courses can fulfil within institutions of higher education. The commercial, economic, and strategic institutional dimensions behind this phenomenon should be more deeply analysed, in addition to the inherent link to the learning quality. The will to expand to a broader public and other markets and the strategies for internationalization, which also pursue greater expansion in economically critical times, has made some institutions consider MOOCs as a good informational instrument for the organizations themselves. Finally, the degree to which MOOCs can be used to supplement or even replace the current model of delivery in small to medium sized lecture halls, directed at current campus students, remains very contentious.

On the other hand, and despite the fact that massification has never been a characteristic of success, MOOCs defenders embrace this concept because they believe that the availability of information to thousands of people engaged in learning processes could help to better understand how people learn. This belief drives emerging disciplines including learning analytics (Campbell, DeBlois and Oblinger, 2007) and educational data mining.

Examining a MOOC in a particular university and degree of controversy surrounding it ranges from a less controversial position when it is used primarily for commercial purposes (attracting students, brand recognition, advertising, etc.) to a more highly debated position when it represents a major disruption in the pedagogical field (Feldstein, 2014).

Although it is possible that there are other lesser-known models, when speaking of MOOCs, we should bear in mind that there are two major types that draw media attention: the cMOOC and the xMOOC. The first follows the principles of connectivism (Siemens, 2004), which believes that learning is generated on the network, starting with the contact and relations that are established between the nodes (people and resources) of the network. It argues that the knowledge created in a network is larger and more powerful than that created individually. The cMOOCs make resources available to those who would like to share them, encourages production by students of additional resources and suggests generating interactions with peers in order to expand knowledge.

The xMOOCs have a much simpler structure. Their approach replicates more traditional teaching methods: a set of resources, typically audio visual-in many cases recordings of in-class lectures-is made available to anyone who would like to use them. The purpose of the xMOOC is to transmit content, to which self-study activities or peer discussions are added for those who would like to complete the course. The 
feedback is usually automated, and the assessment is carried out by objective, automated tests. Recently, revenue models are being developed for xMOOCs in which students pay for additional machine marked assignments to earn a certificate of completion.

Therefore, MOOCs cannot be spoken of in a uniform voice. Some voices in the debate refer to the educational design of the MOOCs as a key factor in their success (Guàrdia, Maina and Sangrà, 2013; Conole, 2014; Ramírez, 2014). However, it is clear that none of these models has yet developed mechanisms sufficiently robust to help us understand what and how much the participants have actually learned at the end of neither the process nor what should be the main objective of this new scalable model with capacity to reach any who wants to learn.

On the other hand, while some of the critiques of the MOOCs question the vanity of the professor who will become known worldwide through the videos, there are enthusiastic professors who see in this initiative an opportunity to change their teaching methods (Daniel, 2012) in order to teach better, to help their students learn more and learn it more effectively, and to offer them more learning opportunities. In short, to experiment and improve higher education.

Another point of dispute has been, and is, the success of the participants. Of course, any definition of success could and should be debatable. Nevertheless most of the sensational news has only been about how many students sign up for a MOOC, not about how many finish it. The percentage of dropouts in the MOOCs is very high -much higher than in other online education models. Most authors place this dropout percentage between 87\% (Onah, Sinclair and Boyatt, 2014) and 95\% (Ho et al., 2014), surpassing 90\% (Rivard, 2013).

There are studies that claim that after the first week, overcoming the pull factor or the novelty, the participation and collaboration index among students drops dramatically, and in some cases becomes non-existent (Lin, 2013).

With this data, some authors show that the dropout percentage is not important (Wright, 2014), or that many only want to learn, and that when they have learned what they want, they drop the course (Devlin, 2013). It is possible. Even so, maybe we should speak more about disclosure than training. Or perhaps the MOOCs are better suited to certain student profiles, those who are self-taught, prefer to be, and are capable of achieving their educational goals without any specific support. In any case, it raises doubts as to whether MOOCs actually achieve their goals and what precisely these goals are. The traditional online assessment systems, with objective, multiple choice questions, commonly used in xMOOCs, reveal little about the learning competencies the participant has acquired.

Finally, another no less important cause for debate is the business model that is needed to sustain MOOCs. Without a doubt, the fact that they are offered for free has had a lot to do with the positive perception that many people have of MOOCs. Applying 
the theory of disruptive innovation by Clayton Christensen (Christensen, Johnson and Horn, 2008), the appearance on the market of a low end offer that breaks the existing cost structure (tuition and university fees) and offers a product that, even though it is likely of lesser quality, but which is much more affordable to the population, could become the dominant model in the future.

However, the MOOCs economic models are in no way clear, not even for those businesses that have leapt at the opportunity to invest in this field. No doubt these companies (and institutions) are experimenting with different models to see which of them has most favourable results (Haché and Punie, 2012; Pedreño et al., 2013).

Universities are thus forced to take into consideration all of the issues discussed above before developing a position on their own involvement in MOOCs. The study carried out by Hollands and Thirtali (2014) synthesized the possible reasons why those institutions of higher education have embraced the MOOC phenomenon with an unusual enthusiasm:

- $\quad$ Extending reach and access.

- $\quad$ Building and maintaining a brand.

- $\quad$ Improving economics: reducing costs or increasing revenues.

- Improving educational outcomes.

- Innovation in teaching and learning.

- $\quad$ Research on teaching and learning.

This last point is the most relevant for this study's objectives. So far, most of the debate on MOOCs has moved within a framework of opinions, both favourable and unfavourable, which are not based on evidence. Many of these and other claims have not been subject to a rigorous and reliable evaluation.

The elements that previously were considered pieces of the MOOC debate have generated, as already mentioned, many more questions than answers. What is the level or the depth of learning that can be achieved with the MOOCs? Is there a sustainable business model that allows offering quality online courses completely free? If this model exists, for whom is it sustainable and who benefits from it? What are the pedagogical innovations that MOOCs are contributing with? How can we really know that the participants in a MOOC reach their personal goals? What does quality mean in a MOOC? Only through sustained and systematic research can we hope to answer questions and more.

In 2012, Liyanagunawardena, Adams and Williams (2013) conducted a systematic review of the literature that had been published up to that time in reference to the MOOC phenomenon. However, what has been published in the subsequent two years exceeds that which was analysed during the four previous years. For this reason, it was considered very important to carry out a new study that would go beyond opinions and the presentation of specific experiences, and would concentrate on those publications presenting research findings that shed more light on the significance and potential of these types of courses. 
This article presents a meta-analysis of the literature from the two year period of 2013-2014 which represents an improvement with respect to that carried out by the authors cited from 2008 to 2012, concentrating in particular on those publications that present results from research focussed on MOOCs.

\section{METHOD}

The literature review model used followed the procedures from Liyana, Gunawardena, Adams and Williams (2013). They used criteria from Fink (2010) in a standardized manner such so that others could replicate the identification methods for papers liable to be considered. This article takes as its starting point that methodology, which consists of identifying relevant papers for the review in progress beginning with an inquiry into reputed journals in the field, databases, search engines, and other systematic reviews that could be accessed. Therefore, and following this example, we searched for research results that used the same key words used in the baseline (2013) study.

- $\quad$ MOOC

- $\quad$ Massively Open Online Course

- $\quad$ Massive Open Online Course

To avoid the problems which Liyanagunawardena, Adams and Williams (2013) found (for example, that in the revision of certain journals featured in the field only one provided articles about the topic and that none of these were relevant), the search began in academic data bases: ISI Web of Knowledge, ProQuest (ERIC, British Education Index and Australian Education Index), JSTORE (Education titles), IEEEXplorer, and SCOPUS. As in the study referred to, some of the articles were rejected because they did not reflect the study's thematic area, even though the MOOC acronym was included.

We selected only those papers that presented an empirical study on MOOCs, rejecting theoretical articles, political reports, and position papers, as well as those that only presented an opinion or intuition about the phenomenon in question. 
Finally, the linking/feedback technique of Gao, Luo and Zhang (2012) which helped us locate addition papers that are highlighted in the studied literature.

Using these strategies we located a total of 228 papers, that were published in 2013 and the nine first months of 2014.

The analysis' process was as much quantitative as qualitative. The quantitative analysis consisted of the classification of the papers according to the publication year and type in which it appeared, as well as their classification by categories. For the qualitative analysis, and given that the intention was to identify the research areas on which the studies focused, categories that Hollands and Tirthali (2014) used were applied and adapted to identify the areas in which research on MOOC seemed to be advancing and which raised the interest of the institutions' directors who were interviewed in the study.

The initial categories were as follows:

1. The role of social networks in teaching and learning.

2. Testing pedagogical strategies.

3. Student engagement and motivation.

4. Machine learning/modelling research.

5. Natural Language processing.

6. Human-computer interaction.

7. Personalized/adaptive learning.

8. Comparing hybrid courses with traditional ones.

9. Developing data standards and a common platform for data mining.

We found additional foci of these research studies that could not be classified using the categories above, so we added two emergent categories.

10. Institutional objectives, consequences for the higher education system.

11. Cultural and accessibility issues. 


\section{RESULTS}

To present the results, two perspectives were followed: quantitative and qualitative. A quantitative perspective offered a panoramic view of the papers found, taking into account various classification criteria: specifically, their publication year, the publication's typology and the topic referred to according to the categories that had been considered in the review that were based on the studies found. While in the latter case the quantitative and qualitative perspectives were combined in the sense that the location of the studies in the categories-and, even more so, the definition of those same categories- followed a process of content analysis and the approximation and review on the line of a qualitative approach. Ultimately, the quantification was made posterior to the definition of categories and the publication's distribution process in those categories. It should be noted, also, that some of the studies -upon taking into account the contents addressed- were placed into more than one category.

\section{Table 1}

Papers per publication year

\begin{tabular}{ll}
\hline Year & \# Studies \\
\hline 2013 & 87 \\
2014 & 141 \\
\hline Total & 228
\end{tabular}

As explained above, this review is limited to the years 2013 and 2014. Table 1 shows the distribution by publication year: 87 studies on MOOC found in 2013 while in 2014 the number rises considerably to 141 studies. If the previous work referenced in order to develop the present review is taken into account, the upward trend in the number of publications noted in 2012 continues and resulted in increases in the following two years. As was to be expected after the progression observed by Liyanagunawardena, Adams and Williams (2013), the MOOC phenomenon has aroused great interest in the educational community. The rapid growth in numbers of publications is a clear reflection of the enthusiasm that MOOCs awakened and the fascination of diverse agents within the educational community find in an initiative that still raise as much doubt about the possibilities of the business and success that the 
massive open online course can generate. Specifically, Liyanagunawardena, Adams and Williams (2013) identified a single paper in 2008 and another in 2009, seven in 2010, ten in 2011, and twenty-six in 2012. That is to say that between the years 2012 and 2013 the publications about MOOC tripled and in two years (from 2012 to 2014) they multiplied by five.

In addition, it should be noted that the publications that were collected by Liyanagunawardena, Adams and Williams (2013) were not strictly research but about any aspect related to the MOOCs. Hence, one of the conclusions that should be mentioned is not only the impact that MOOCs have created quickly and expansively, but also that they have given rise to empirical studies that allow a review of their contributions. These research articles begin to provide evidence of what they might mean in the online education field, as well as the optimal conditions needed to make their design and development more effective (Guàrdia, Maina and Sangrà, 2013; Conole, 2014; Ramírez, 2014).

Table 2

Paper distribution by publication type

\begin{tabular}{llll}
\hline Code & Type & \# & $\%$ \\
\hline A & Articles & 112 & 49.12 \\
B & Conference proceedings & 97 & 42.55 \\
C & Newspapers & 4 & 1.75 \\
D & Reports & 7 & 3.07 \\
E & Workshops & 3 & 1.32 \\
F & Books/essays & 5 & 2.19 \\
\hline & Total & 228 & 100.00
\end{tabular}

Table 2 contains the division of papers according the means of publication. It should be noted that almost half of the publications were disseminated through academic journal articles (49.12\%). The articles were distributed in 48 journals, 26 of which are open access and 22 have restricted access or are distributed only by purchase. 
The second most widely used means of circulation has been through presentations at conferences (42.54\%). The following publication methods have had limited use: $3.07 \%$ in reports; $2.19 \%$ in books or essays; $1.75 \%$ in informative periodical publications and $1.31 \%$ in workshops or seminars.

In terms of journal publications, it is worth noting that several have been in special issues focussed on MOOCs. These include special issues in the British Journal of Educational Technology (BJET), The International Review of Research in Open and Distance Learning (IRRODL), Journal of Universal Computer Science (JUCS), International Journal of Distance Education Technologies (IJDET) and Journal of Computer Assisted Learning (JCAL).

It is surprising that the number of papers published in article format is higher than conference presentations. Scientific meetings, whatever their organizational structure (symposium, conference, meeting...) are much more flexible and immediate as a showcase for the latest scientific advances and as a forum for debate and corroboration with colleagues on the newest initiatives or on experimental phases of research. We also note that in some cases studies presented first in conferences were subsequently published in journals (above all in monographic issues) and for this reason the number of studies in journal articles is greater.

In the period of this study seven reports were identified, mostly produced or commissioned by institutions and organizations whose intentions was to respond to a need for a panoramic view of the MOOCs and, above all, to inquire into several economic, academic, administrative and pedagogical implications. Titles of these reports below are a sample of the purpose and scope of the reports produced:

- $\quad$ MOOCs: expectations and reality. Full report (Center for Benefit-Cost Studies of Education Teachers College, Columbia University).

- $\quad$ An avalanche is coming (Institute for Public Policy Research)

- $\quad$ The pedagogy of the Massive Open Online Course: the UK view (The higher education academy) 
- Structural limitations of learning in a crowd: communication vulnerability and information diffusion in MOOCs (Scientific Reports 4, Article number: 6447, Published 23 September 2014)

$\begin{array}{llllll}\text { - } & \text { MOOCs } @ \text { Edinburgh } 2013 & - & \text { report } \\ \text { (https://www.era.lib.ed.ac.uk/handle/1842/6683) }\end{array}$

In terms of the number of books published in this time period, it is important to note that publications in book format require more time to edit and circulate, and have more cumbersome procedures for their acceptance by publishers. However, like the reports the titles of these book publications show the concerns of the institutions of higher education regarding MOOCs. Thus, two publications, one in 2013 and one in 2014, were published with support from the EUA (the European University Association). In addition, a book about MOOCs in the United Kingdom MOOC: Massive open online courses. Higher education's digital moment? (London: Universities UK Publications) was published.

Table 3

Paper distribution by year and publication type

\begin{tabular}{llcccc}
\hline & & 2013 & \multicolumn{3}{c}{2014} \\
\hline Code & Type & $\#$ & $\%$ & $\#$ & $\%$ \\
\hline A & Articles & 37 & 42.52 & 75 & 53.19 \\
B & Conference proceedings & 40 & 45.98 & 57 & 40.42 \\
C & Newspapers & 4 & 4.60 & 0 & -- \\
D & Reports & 3 & 3.45 & 4 & 2.84 \\
E & Workshops & 0 & -- & 3 & 2.13 \\
F & Books/essays & 3 & 3.45 & 2 & 1.42 \\
\hline & Total & 87 & 100.00 & 141 & 100.00
\end{tabular}

As shown in Table 3, the proportion of the studies according to the year and type of publication is quite similar.. Nevertheless, there are differences, which though minimal, are worth comment. Firstly, note the significant increase in publications in journals. As has been stated, the publication of a paper -especially in indexed journalsis subject to a review process -and in most cases resulting in changes requested of the 
authors-often resulting in delays from months up to a year or more. This may be one of the causes for the difference in the number of publications found in those years.

The number of conference presentations has also risen indicating the importance of MOOCs for researchers and scholars, as is reflected in the various events that have taken place in both periods. It should be noted that the conferences that have included MOOC presentations are varied in topics, and include as many meetings of a more technological or management nature as those of a more educational one. Take the following conferences for example:

- Advanced Learning Technologies (ICALT), 2014 IEEE 14th International Conference on (LOOCs -- Linked Open Online Courses: A Vision).

- $\quad 3 r d$ International Conference on Education and Education Management (EEM) Location: Singapore, SINGAPORE Date: NOV 15-16, 2013 (The Bilingual Teaching Reform Combined with MOOC)

For their part, educational conferences prioritize those aspects relative to learning through MOOCs:

- Proceedings of the European Conference on e-Learning, ECEL (Something for everyone: MOOC design for informing dementia education and research).

- IADIS International Conference on Cognition and Exploratory Learning in Digital Age, CELDA 2013 (Developing a connectivist MOOC at a college of education: Narrative of disruptive innovation?

This brings attention to the fact that in 2013 there was no workshop that included topics about MOOCs and that of the three papers developed in 2014, two were presented at the same event: 3rd International Workshop on Learning Technology for Education in the Cloud, LTEC 2014; Santiago; Chile; 2 September 2014 through 5 September 2014; Code 10735. 
Table 4

Distribution of studies by topic category

\begin{tabular}{llrr}
\hline Code & Category & $\#$ & $\%$ \\
\hline 1 & The role of social networks in teaching and & 53 & 23.24 \\
& learning & & \\
2 & Testing pedagogical strategies & 84 & 36.84 \\
3 & Student engagement and motivation & 64 & 28.07 \\
4 & Machine learning/modelling research & 16 & 7.02 \\
5 & Natural Language processing & 15 & 6.58 \\
6 & Human-computer interaction & 38 & 16.67 \\
7 & Personalized/adaptive learning & 16 & 7.02 \\
8 & Comparing hybrid courses with traditional ones & 22 & 9.65 \\
9 & Data standards and common platform for data & 43 & 18.86 \\
& mining & & \\
10 & Institutional objectives, consequences for the & 51 & 22.37 \\
& higher education system & & \\
11 & Cultural and accessibility issues & 16 & 7.02
\end{tabular}

As is noted above, the categories used to thematically classify the papers that were found in the bibliographical review emerged from a dual process that can be classified as deductive and inductive: initially, the nine categories collected by Hollands and Tirthali (2014) were used and, upon applying them to organize the publications, it was noted that two more categories were needed to bring together certain aspects of the research that could not easily be placed in the previously selected nine. Thus the total number of categories included was eleven.

Some of the papers were coded in more than one category taking into account the topics addressed in the work. Thus, the total sum of the reviewed publications in Table 4 exceeds the 228 studies that were reviewed (though the percentage is calculated with reference to the 228 studies found).

The data collected in Table 4 affirms that more than one third of the research about MOOCs has been oriented toward testing pedagogical strategies: for example, 
content co-creation and participatory pedagogy (Anderson and Ponti, 2014); or MOOC design for the levelling of knowledge (Daza, Makriyannis and Rovira Riera, 2013). More than a quarter of the studies focused on studying student engagement and motivation: evaluation of support systems for students (Stewart et al., 2013), reasons to enrol in a MOOC and learning experience (Zutzhi, O’Hare and Rodafinos, 2013); or strategies to encourage participation (Kizilcec et al., 2014). A similar percentage of studies attempted to respond to two far-reaching social and institutional issues: for category one, exploring the role of social media in education: the use of 2.0 tools for learning (Alario-Hoyos et al., 2014); or how to learn to collaborate on online networks and offline (Schreurs et al., 2014); and with respect to category ten, identifying how to cover institutional objectives, consequences for the higher education system: strategies for internationalization (Marshall, 2013), economic and system sustainability analysis (Hoxby, 2014), or changes in institutional dynamics (O’Connor, 2014). The following categories that attracted research interest are referred to as data standards and common platform data mining (18.86\%): an analysis of the use of resources with respect to the time spent with each one (Breslow et al., 2013); or navigation strategies according to age and country of origin (Guo and Reinecke, 2014) and human-computer interaction (16.67\%): adapting the machine to student progress (Vargas, 2014). The following categories have been least researched and the number of studies found does not reach $10 \%$ in any case. Such is the situation of the categories relating to comparing between hybrid courses with traditional ones, machine learning/modelling research, personalized/adaptive learning as well as cultural and accessibility questions.

Table 5

Distribution of papers by year and publication type

\begin{tabular}{llcccc}
\hline & & \multicolumn{3}{c}{$2013^{1}$} & \multicolumn{2}{c}{$2014^{2}$} \\
\hline Code & Category & $\#$ & $\%$ & $\#$ & $\%$ \\
\hline 1 & The role of social networks in teaching and & 16 & 18.39 & 37 & 26.24 \\
& learning & & & & \\
2 & Testing pedagogical strategies & 35 & 44.82 & 49 & 34.75 \\
3 & Student engagement and motivation & 19 & 21.84 & 45 & 31.91 \\
4 & Machine learning/modelling research & 5 & 5.75 & 11 & 7.80 \\
5 & Natural Language processing & 6 & 6.90 & 9 & 6.38
\end{tabular}


Human-computer interaction

19

21.84

19

13.47

7

8

Personalized/adaptive learning

5

5.75

11

8

Comparing hybrid courses with traditional 12

13.79

10 ones

9

Data standards and common platform for 13

14.94

30

21.28 data mining

10

Institutional objectives, consequences for

24

27.59

27

19.15

the higher education system

11

Cultural and accessibility questions

4

4.60

12

8.51

As shown in Table 5, some differences in several categories and also certain coincidences can be seen in the studies' distribution by year and thematic category.

Thus, both in 2013 and 2014, the research focused on testing pedagogical strategies (44.82\% in 2013 and $34.75 \%$ in 2014). The second topic of greatest interest in 2013 was the scope of the MOOCs in terms of the institutions' objectives and their consequences for the higher education system (27.59\% in 2013 and a bit less in 2014 at 19.15\%). In 2014 the second topic receiving the most research was about student engagement and motivation (31.91\% in 2014 and a bit less in 2013 at $21.84 \%$ ).

In 2013 there was also a rise in the interest in topics such as the possibility of human-computer interaction (21.84 \%). In the same year, studies on the role of social medial in teaching and learning (18.39\%); developing data standards and a common platform for data mining (14.94\%) or comparing between hybrid courses with traditional ones (13.79\%) were also published.

2014 recorded a good number of studies about the role of social media in teaching and learning, which accounted for (26.24\%). The concern remains for developing data standards and a common platform for data mining (21.28\%) and the 
analysis of institutions' objectives and the consequences for the higher education system (19.15\%).

Table 6

Distribution of papers by publication type and thematic category

\begin{tabular}{|c|c|c|c|c|c|c|c|c|c|c|c|c|c|c|}
\hline & Publication type & Art & & Cor & ference & & spaper & & port & & rkshop & $\mathrm{Bc}$ & ok & \\
\hline Cod. & Category & $\#$ & $\%$ & \# & $\%$ & $\#$ & $\%$ & \# & $\%$ & $\#$ & $\%$ & $\#$ & $\%$ & Total \\
\hline 1 & $\begin{array}{l}\text { The role of social } \\
\text { networks in teaching } \\
\text { and learning }\end{array}$ & 32 & 60.37 & 17 & 32.07 & 1 & 1.89 & 1 & 1.89 & 1 & 1.89 & 1 & 1.89 & 53 \\
\hline 2 & $\begin{array}{l}\text { Testing pedagogical } \\
\text { strategies }\end{array}$ & 48 & 57.15 & 31 & 36.90 & 2 & 2.38 & 2 & 2.38 & 0 & --- & 1 & 1.19 & 84 \\
\hline 3 & $\begin{array}{l}\text { Student engagement } \\
\text { and motivation }\end{array}$ & 34 & 53.13 & 25 & 39.06 & 1 & 1.56 & 0 & --- & 1 & 1.56 & 3 & 4.69 & 64 \\
\hline 4 & $\begin{array}{l}\text { Machine } \\
\text { learning/modelling } \\
\text { research }\end{array}$ & 4 & 25 & 12 & 75 & 0 & --- & 0 & --- & 0 & --- & 0 & --- & 16 \\
\hline 5 & $\begin{array}{l}\text { Natural Language } \\
\text { processing }\end{array}$ & 8 & 53.33 & 5 & 33.33 & 0 & --- & 1 & 6.67 & 0 & --- & 1 & 6.67 & 15 \\
\hline 6 & $\begin{array}{l}\text { Human-computer } \\
\text { interaction }\end{array}$ & 10 & 26.31 & 27 & 71.06 & 0 & --- & 0 & --- & 0 & --- & 1 & 2.63 & 38 \\
\hline 7 & $\begin{array}{l}\text { Personalized/adaptive } \\
\text { learning }\end{array}$ & 9 & 56.25 & 6 & 37.5 & 0 & --- & 0 & --- & 0 & --- & 1 & 6.25 & 16 \\
\hline 8 & $\begin{array}{l}\text { Comparing hybrid } \\
\text { courses with } \\
\text { traditional ones }\end{array}$ & 12 & 54.55 & 7 & 31.83 & 1 & 4.54 & 1 & 4.54 & 0 & --- & 1 & 4.54 & 22 \\
\hline 9 & $\begin{array}{l}\text { Data standards and } \\
\text { common platform for } \\
\text { data mining }\end{array}$ & 11 & 25.59 & 28 & 65.12 & 0 & --- & 1 & 2.32 & 2 & 4.65 & 1 & 2.32 & 43 \\
\hline 10 & $\begin{array}{l}\text { Institutional } \\
\text { objectives, } \\
\text { consequences for the } \\
\text { higher education } \\
\text { system }\end{array}$ & 25 & 49.03 & 13 & 25.49 & 2 & 3.92 & 5 & 9.80 & 1 & 1.96 & 5 & 9.80 & 51 \\
\hline 11 & $\begin{array}{l}\text { Cultural and } \\
\text { accessibility issues }\end{array}$ & 8 & 50 & 5 & 31.25 & 1 & 6.25 & 1 & 6.25 & 1 & 6.25 & 0 & --- & 16 \\
\hline
\end{tabular}


This data was then analysed based on results that are reflected in Table 6, which publication formats were used most per each of the established eleven thematic categories.

More than half of the studies that referred to the role of social media in teaching and learning were published in articles (60.37\%). A third of that research into this line of inquiry was presented at conferences (32.07\%). The rest of the circulation media was used far less.

In addition, more than half of the studies related to testing pedagogical strategies are found in journal publications (57.15\%), although they have considerable representation in conferences on this topic (36.90\%).

There is a high percentage of analysis on student engagement and motivation in articles (53.13\%) and in conferences (39.06\%). It is also worth mentioning that $4.69 \%$ of the studies were collected in books.

Three quarters of the research on machine learning/modelling were presented mostly in conferences and a quarter was found in articles. No studies of this nature were found in other channels followed by the review.

Half of the research about natural language processing was found in articles (53.33\%). A third of the studies were presented in conferences (33.33\%).

As to the analysis on human-computer interaction, above all, conference publications should be consulted (71.06\%). A quarter of the studies were collected in articles (26.31\%) and to a much lesser extent in books (2.63\%).

More than half of the analysis on personalized/adaptive learning (56.25\%) and that of comparing hybrid courses and traditional ones (54.55\%) were published in journals with specialized distribution channels. Nevertheless, the choice to present research on these topics in conferences was hardly negligible (37.5\% and $31.83 \%$ respectively). 
About developing data standards and common platform for data mining, research was presented mostly in conferences (65.12\%), although a quarter was disseminated through articles (25.59\%). One explanation for this trend is the fact that the author profile for this type of research is computer science or telecommunications engineers, who tend to disseminate the results of their work in conferences in their area of knowledge. This area highly values this type of presentation, since most of these conference proceedings are indexed in prestigious academic databases (i.e. ISI Web of Knowledge, ProQuest) and gives them a widespread audience. Eventually, they decide to publish another version of the research in a journal article.

In terms of studies reviewed in the last two categories, institutions' objectives and the consequences for the higher education system, as well as on cultural and accessibility questions: half of them were published as journal articles and one-third were presented in conferences.

\section{DISCUSSION AND CONCLUSIONS}

The increase of publications presenting empirical studies and, particularly, their relevant magnitude in the years 2013 and 2014, demonstrates that the MOOC phenomenon has entered into a new stage that seeks for an explanation of its meanings and the contrast that demonstrate that the results that can be obtained in scientifically rigorous research projects, in line with what some authors were already demanding (Bates, 2014; Veletsianos, 2014).

Research topics, which have been categorized using the classification of Hollands and Tirthali (2014), do not completely follow experts' expectations on an agenda for MOOC research. Thus, Downes (2013) noted that the Bill and Melinda Gates Foundation promotes some topics to be studied that have as priority points: identifying the type of data which is necessary to promote the advancement of learning, the aims and designs of different types of MOOCs, the types of students, courses and contexts for which MOOCs are effective, the depth of learning with MOOC, the MOOC components that most impact participants' learning, the teachers’ roles, temporary and 
different working conditions between traditional learning and online learning, costs and obstacles to their development, and the objectives that both students and institutions can reach through MOOCs.

For his part, Bates (2014) stresses the importance of inquiring into what MOOC participants learn, their costs and the possibilities of developing economies of scale, the impact on the institutional brand, ethical issues and the response to the students' needs in the digital age.

Of the work done, it can be deduced that although some of these aspects are referred to in the various publications analysed. A very important part of the research is oriented toward technological solutions (machine learning/modelling, human-computer interaction, natural language processing, data mining and learning analytics). This is likely due, on the one hand, to the fact that the xMOOCs (already referred to in this article, which make up the majority at this point), have their genesis in the engineering field; and practitioners who took the business initiatives that drove this phenomenon (Coursera, edX, Udacity) also have engineering backgrounds. Secondly, key component of the scalability of MOOCs relate to using advanced technologies to replace or supplement much of the student-teacher and student-student interaction found in less scalable models of both online and campus education.. The majority of conference presentations analysed in the two years reviewed come from events in the informatics and telecommunications area (Learning at Scale International Conference, Association of Computer Machinery (ACM)); EDUCON IEEE International Conference).

Another reason that could explain the focus on technological solutions is that current business models do not guarantee the sustainability of the initiative (Haché and Punie, 2012), thus, there is a pressing need to find proposals that drastically reduce the MOOCs' development and maintenance costs. Automating the teaching process, and the consequent reduction of teacher intervention, is seen as a possible avenue to explore.

However, it should be noted that the most researched topics refer to testing pedagogical strategies and, particularly, student engagement and motivation. Hence, the criticism—even by some of this modality’s strongest advocates (Siemens, 2012)—about 
the absence of teaching innovation in the xMOOC have become evident, at the same time that there is great concern about the lack of learning continuity-and the consequent dropout rate-in the majority of these courses participants. These pedagogical issues are used as evidence to criticize the so-called success of the MOOCs, and by those who want to find interpretations that allow them to continue defending the MOOCs validity (Devlin, 2013; Ho et al., 2014).

This study shows that there is an upward trend in the volume of publications and the predilection for them to be published as journal articles and, to a lesser extent, conference presentations. It is noteworthy that many articles are published in open journals, following the philosophy of this movement, of which the MOOCs could be a paradigmatic standard. Open and online journals allow for faster publication and facilitate greater reader access. In addition, having seen the special issues already mentioned which are in preparation, it is likely that a new literature review will be advisable in a reasonable period to verify and check the advancements achieved.

From a pedagogical point of view, the scope of the MOOC phenomenon for online teaching is functioning as a wakeup call which questions. It challenges on the one hand, the institutions in terms of their current structure, teaching model, and their management and business models. On the other hand, however, it also has important implications for teaching and, in particular, online teaching. The issue is made even more relevant in the analysis and development of the roles and competences that online teachers should assume and acquire to perform successfully in changing virtual environments (Muñoz-Carril; González-Sanmamed and Hernández-Sellés, 2013; González-Sanmamed; Muñoz-Carril, and Sangrà, 2014).

The considerable amount of information created by this phenomenon will require answers that should be based on evidence from practice. That is why it will be necessary to agree on a schedule for the topics and the most useful studying methods so that their impact can be suitably resourced to benefit the progress to a more open yet high quality education. 


\section{REFERENCES}

Alario-Hoyos, C.; Pérez-Sanagustín, M.; Delgado-Kloos, C.; Parada G., H.A. and Muñoz-Organero, M. (2014). Delving into Participants' Profiles and Use of Social Tools in MOOCs, IEEE Transactions on Learning Technologies, 7(3), 260266.

Allen, I.E. and Seaman, J. (2013). Changing Course: Ten Years of Tracking Online Education in the United States. Wellesley, MA: Babson College/Quahog Research Group.

Andersen, R. and Ponti, M. (2014). Participatory pedagogy in an open educational course: challenges and opportunities, Distance Education, 35(2), 234-249.

Bates, A.W. (2014, Octubre 19). The strengths and weaknesses of MOOCs: Part I [blog post]. Recuperado de http://www.tonybates.ca/tag/moocs/

Bates, A.W. and Sangrà, A. (2011). Managing Technology in Higher Education. Strategies for Transforming Teaching and Learning. San Francisco: JosseyBass.

Breslow, L.; Pritchard, D.E.; DeBoer, J.; Stump, G.S.; Ho, A. and Seaton, D.T. (2013). Studying Learning in the Worldwide Classroom Research into edX's First MOOC, Research \& Practice in Assessment, 8, 13-25.

Campbell, J.P., Deblois, P.B. and Oblinger, D.G. (2007). Academic analytics: A new tool for a new era. EDUCAUSE Review, 42(4), 41-57. Recuperado de http://net.educause.edu/ir/library/pdf/ erm0742.pdf

Christensen, C.; Johnson, C.W. and Horn, M.B. (2008). Disrupting Class: How Disruptive Innovation
Will Change the Way the World Learns. New York: McGraw-Hill.

Conole, G. (2014, Mayo 14). Good practice in design and delivery of MOOCs [blog post]. Recuperado de http://e4innovation.com/?p=801.

Contact North (2014). Understanding the Building Blocks of Online Learning. Recuperado de http://contactnorth.ca/sites/default/fil es/pdfs/understanding_the_building blocks_of_online learning_2014.pdf

Daniel, J. (2012). Making Sense of MOOCs: Musings in a Maze of Myth, Paradox and Possibility. Journal of Interactive Media in Education 2012(3):18, DOI: http://dx.doi.org/10.5334/2012-18

Daniel, J.; Kanwar, A. and UvalicTrumbic, S. (2009). Breaking Higher Education's Iron Triangle: Access, Cost, and Quality, Change, marchapril, 2009. Recuperado de http://www.changemag.org/archives/ back\%20issues/marchapril\%202009/full-iron-triangle.html

Daza, V.; Makriyannis, N. and Rovira Riera, C. (2013). MOOC attack: closing the gap between preuniversity and university mathematics, Open Learning: The Journal of Open, Distance and $e$ Learning, 28(3), 227-238

Devlin, K. (2013, Febrero 3). MOOCs and the Myths of Dropout Rates and Certification [blog post]. Recuperado de

http://www.huffingtonpost.com/drkeith-devlin/moocs-and-the-mythsof-dr_b_2785808.html

Downes, S. (2013, Abril 4). Digging into MOOC Mania: One Investor's Key Research Questions and Approach [blog post]. Recuperado de http://halfanhour.blogspot.com.es/20 
13/04/digging-into-mooc-mania-oneinvestors.html

Feldstein, M. (2014, Octubre 22). Keynote: The Year after the Year of the MOOC [blog post]. Recuperado de http://mfeldstein.com/keynoteyear-year-mooc/

Fink, A. (2010). Conducting research literature reviews: From Internet to paper ( $3^{\text {rd }}$ ed.). Thousand Oaks, California: Sage.

Gao, F.; Luo, T. and Zhang, K. (2012). Tweeting for learning: A critical analysis of research on microblogging in education published in 2008-2011. British Journal of Educational Technology, 43(5), 783-801.

González-Sanmamed, M.; MuñozCarril, P. and Sangrà, A. (2014). Level of Proficiency and Professional Development Needs in Peripheral Online Teaching Roles, The International Review of Research in Open and Distance Learning (IRRODL), 15(6), 162-187.

Guàrdia, L.; Maina, M. and Sangrà, A. (2013). MOOC Design Principles. A Pedagogical Approach from the Learner's Perspective, eLearning Papers, 33. 1-6. Recuperado de http://www.openeducationeuropa.eu/ en/article/MOOC-Design-

Principles.-A-Pedagogical-

Approach-from-theLearner\%E2\%80\%99s-Perspective

Guo, P.J. and Reinecke, K. (2014). Demographic Differences in How Students Navigate Through MOOCs, L@S 2014 - Proceedings of the 1st ACM Conference on Learning at Scale 2014, 21-30.

Haché, P. and Punie, Y. (2012). An exploration of business and sustainability models for OER initiatives in Higher Education. Paper presented at the EADTU $25^{\text {th }}$ Anniversary Conference. The Role of
Open and Flexible Education in European Higher Education Systems for 2020: new models, new markets, new media. Paphos, 27-28 September 2012

Ho, A. D., Reich, J., Nesterko, S., Seaton, D. T., Mullaney, T., Waldo, J. and Chuang, I. (2014). HarvardX and MITx: The first year of open online courses (HarvardX and MITx Working Paper No. 1). Recuperado de http://ssrn.com/abstract=2381263

Hollands, F.M. and Tirthali, D. (2014). MOOCs: Expectations and Reality. Full Report. New York: Teachers College, Columbia University.

Hoxby, C.M. (2014). The Economics of Online Postsecondary Education: MOOCs, Nonselective Education, and Highly Selective Education, NBER Working Paper Series, Working Paper 19816. Cambridge, MA: National Bureau of economic Research. Recuperado de: http://www.nber.org/papers/w19816

Kizilcec, R.F.; Schneider, E.; Choen, G.L. and McFarland, D.A. (2014). Encouraging Forum Participation in Online Courses with Collectivist, Individualist and Neutral Motivational Framings, eLearning Papers, 37, 13-22.

Lin, M. (2013, Junio 27). Case study: Low participation rate raises question about effectiveness of Massive Open Online Course (MOOC) [blog post]. Recuperado de http://www.mulinblog.com/casestudy-low-participation-rate-raisesquestion-about-effectiveness-ofmassive-open-online-course-mooc/

Liyanagunawardena, T.R.; Adams, A.A. and Williams, S.A. (2013). MOOCs: A Systematic Study of the Published Literature 2008-2012, The International Review of Research in Open and Distance Learning (IRRODL), 14(3), 202-227. 
Recuperado

de

http://www.irrodl.org/index.php/irro dl/article/view/1455

Marshall, S.J. (2013). Evaluating the Strategic and Leadership Challenges of MOOCs, MERLOT Journal of Online Learning and Teaching, 9(2), 216-227.

Muñoz-Carril, P.; González-Sanmamed, M. and Hernández-Sellés, N. (2013). Pedagogical Roles and Competencies of University Teachers Practicing in the E-Learning Environment, The International Review of Research in Open and Distance Learning (IRRODL), 14(3), 462-487.

O’Connor, K. (2014). MOOCs, institutional policy and change dynamics in higher education, Higher Education, 68, 623-635.

O’Shea, T.; Haywood, J.; Woodgate, A.; Conelly, J.; Gormley, S. and Kendra, $\mathrm{L}$.

(2013). MOOCs@Edinburgh 2013 Report\#1. Edinburg: University of Edinburgh. Recuperado de http://www.shef.ac.uk/polopoly_fs/1. 308890!/file/Edinburgh_MOOCs_Re port_2013_1.pdf

Onah, D.F.O.; Sinclair, J. and Boyatt, R. (2014). Drop Out Rates of Massive Open Online Courses: Behavioural Patterns. Edulearn14, $6^{\text {th }}$ International Conference on Education and New Learning Technologies, Barcelona. Recuperado de http://www2.warwick.ac.uk/fac/sci/d cs/people/research/csrmaj/daniel_ona h_edulearn14.pdf

Pappano, L. (2012, Noviembre 2). The Year of The MOOC, The New York Times [Articulo electrónico]. Recuperado de

http://www.nytimes.com/2012/11/04/ed ucation/edlife/massive-open-onlinecourses-are-multiplying-at-a-rapidpace.html?pagewanted $=$ all\& $\mathrm{r}=0$
Pedreño, A.; Moreno, L.; Ramon, A. and Pernías, P. (2013). La crisis del modelo actual. Los MOOC y la búsqueda de un modelo de negocio, Campus Virtuales, 2(2), 54-65. Recuperado de http://www.revistacampusvirtuales.es images/3/4.pdf

Ramírez, M.S. (2014). Guidelines and Success Factors Identified in the First MOOC in Latin America, Edulearn14, $\quad 6^{\text {th }} \quad$ International Conference on Education and New Learning Technologies, Barcelona. Recuperado de http://catedra.ruv.itesm.mx/bitstream 1987654321/840/2/Guidelines\%20an d\%20success\%20factors\%20identifie d\%20in\%20the\%20first\%20MOOC \%20in\%20Latin\%20America.pdf

Rivard, R. (2013, Marzo 8). Measuring the MOOC Dropout Rate. Inside Higher Ed [Artículo electrónico]. Recuperado de https://www.insidehighered.com/new s/2013/03/08/researchers-explorewho-taking-moocs-and-why-somany-drop-out

Rizvi, S.; Donnelly, K. and Barber, M. (2013). An Avalanche is Coming: Higher Education and the Revolution Ahead. London: Institute for Public Policy Research. Recuperado de http://www.ippr.org/assets/media/im ages/media/files/publication/2013/04 lavalanche-iscoming_Mar2013_10432.pdf

Rumble, G. (Ed.) (2004). Papers and Debates on the Economics and Costs of Distance and Online Learning. Oldenburg: Bibliotheks- und Informationssystem der Universität Oldenburg.

Schreurs, B.; Van den Beemt, A.; Prinsen, F.; Witthaus, G.: Conole, G. and De Laat, M. (2014). An Investigation into Social Learning Activities by Practitioners in Open 
Educational Practices, The International Review of Research of Open and Distance Learning (IRRODL), 15(4), 1-20.

Siemens, G. (2004). Connectivism. A Learning Theory for the Digital Age. Elearnspce, 12 Diciembre 2012. Recuperado de http://www.elearnspace.org/Articles/ connectivism.htm

Siemens, G. (2012, Julio 25). MOOCs are really a platform [blog post]. Recuperado de http://www.elearnspace.org/blog/201 2/07/25/moocs-are-really-a-platform/ Stewart, B.L.; Goodson, C.E.; Miertschin, S.L.; Norwood, M.L. and Ezell, S. (2013). Online Student Support Services: A Case Based on Quality Frameworks, MERLOT Journal of Online Learning and Teaching, 9(2), 290-303.

Vargas, J. (2014). What can online course designers learn from research on machine-delivered instruction? Academe, 100(3), 8-12. Recuperado de

http://search.proquest.com/docview/1 $\underline{532082640 \text { ?accountid }=15299}$

Veletsianos, G. (2014, Junio 5). The research that MOOCs need [blog post]. Recuperado de http://www.veletsianos.com/2013/06/ 05/the-research-that-moocs-need/

Wright, R. (2014, Abril 29). The Death of MOOCs has been greatly exaggerated [Artículo electrónico]. Recuperado de http://www.slate.com/articles/technol ogy/future tense/2014/04/mooc_com pletion_rates_don_t_matter.html

Zutshi, S., O'Hare, S. and Rodafinos, A. (2013). Experiences in MOOCs: The Perspective of Students. American Journal of Distance Education, 27(4), 218-227. 


\title{
AUTHOR'S ACADEMIC AND PROFESSIONAL PROFILES
}

Albert Sangrà, Ph.D., is professor and researcher at the Universitat Oberta de Catalunya (UOC). He is the Academic Director for the UNESCO Chair in Education \& Technology for Social Change at UOC. His research interests are related to online education leadership, management and design, as well as its quality issues. He has been Director, eLearn Center, UOC (2012-2014), and Vice-president of the European Foundation for Quality in E-Learning (EFQUEL) (2011-2014).

Mercedes González-Sanmamed, Ph.D., is full professor and researcher at the Faculty of Educational Sciences, University of A Coruña (UDC), Spain, since 1993. She has got the ANECA's accreditation as full chair professor since 2012. Her research interests are focused on teacher training, integration of ICT into Education, and innovation and educational improvement. She has also been director of the Center for Teacher Training and Educational Innovation (CUFIE) at UDC (2000-2004).

Terry Anderson, Ph.D., is professor and researcher at Athabasca University, Canada. His research interests are related to the use of ICT in education, open, distance and online learning, and the possibilities of educating huge amounts of people through collaborative learning models. He is Director of the Canadian Institute Distance Education Research (CIDER).

\section{AUTHOR'S ADDRESSES}

\author{
Albert Sangrà \\ Universitat Oberta de Catalunya \\ Barcelona Growth Centre \\ Roc Boronat, 177, 6 a planta \\ Barcelona (España) \\ E-mail: asangra@uoc.edu \\ Mercedes González-Sanmamed \\ Universidad de A Coruña \\ Facultad de Ciencias de la Educación \\ Campus de Elviña s/n. 15071 A Coruña (España). \\ E-mail: mercedes@udc.es
}


Terry Anderson

Athabasca University

Peace Hills Trust Tower 1200,

10011 - 109 Street

Edmonton, AB Canada T5J 3S8

E-mail: terrya@athabascau.ca

Fecha Recepción del Artículo: 12. Noviembre. 2014

Fecha Modificación Artículo: 27. Enero. 2015

Fecha Aceptación del Artículo: 30. Enero. 2015

Fecha Revisión para publicación: 30. Enero. 2015 